\section{UCDNN}

LIBRARY
University of Connecticut OpenCommons@UConn

Special Reports

Connecticut Institute of Water Resources

March 1967

\title{
Lectures on Law in Relation to Water Resources Use and Development
}

William C. Kennard, ed.

Institute of Water Resources

Follow this and additional works at: https://opencommons.uconn.edu/ctiwr_specreports

\section{Recommended Citation}

Kennard, ed., William C., "Lectures on Law in Relation to Water Resources Use and Development" (1967). Special Reports. 2. https://opencommons.uconn.edu/ctiwr_specreports/2 
Report No. 2

\section{LECTURES ON LAW IN RELATION TO WATER RESOURCES USE AND DEVELOPMENT}

March 29, 1967

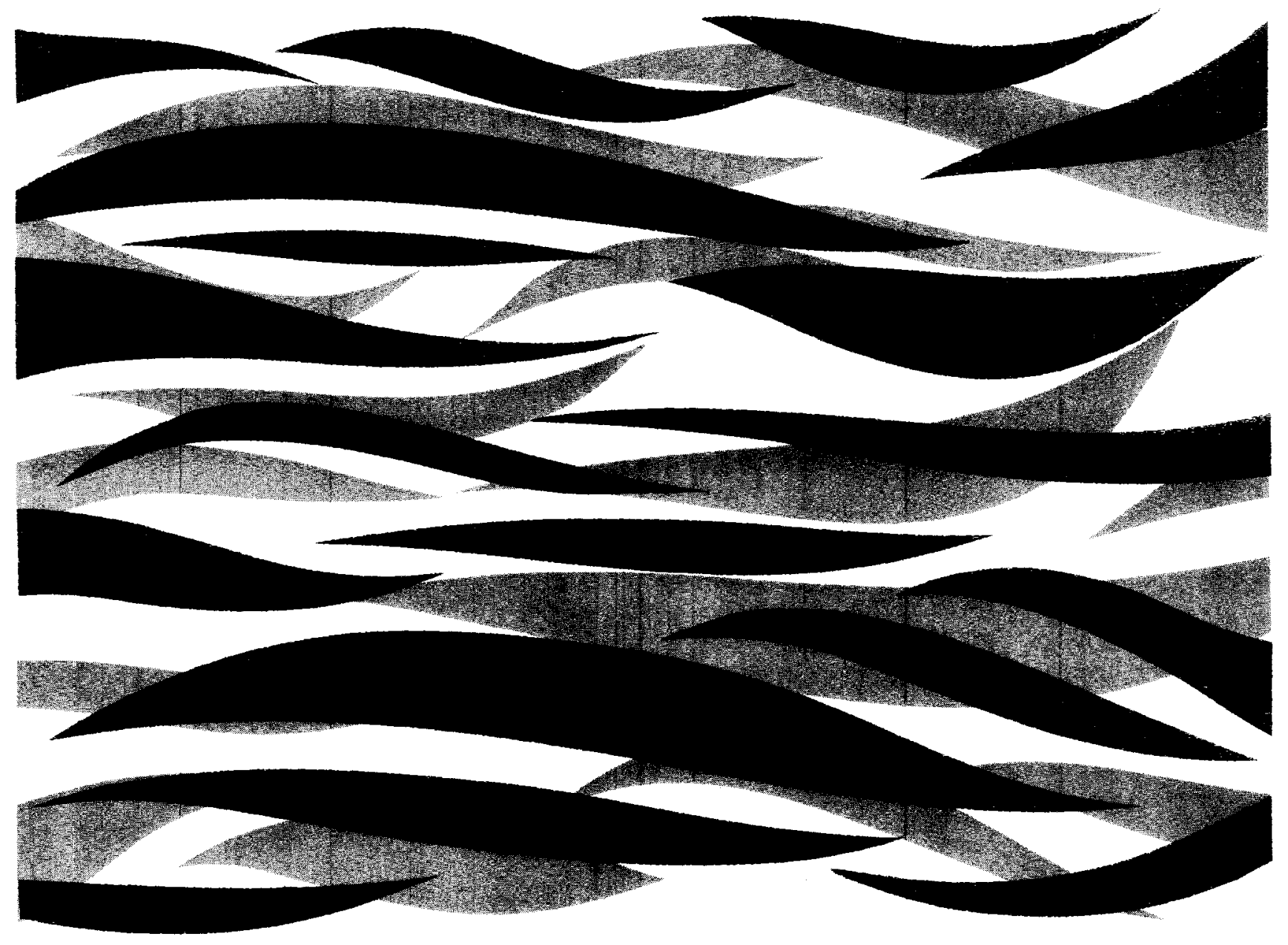

\section{INSTITUTE OF WATER RESOURCES of the University of Connecticut}




\title{
Lectures on Law in Relation to Water Resources Use and Development
}

March 29, 1967

\author{
Edited by \\ William C. Kennard \\ Institute of Water Resources \\ The University of Connecticut \\ Storrs, Connecticut 06268
}

\begin{abstract}
Expenses involved in conducting the seminar lectures and in publishing this Report of the Institute of Water Resources were met with funds provided by the United States Department of the Interior as authorized under the Water Resources Research Act of 1964, Public Law 88-379.
\end{abstract}




\section{FOREWORD}

As part of its ongoing program to develop a greater knowledge of and understanding about water resources use and development, the Institute of Water Resources sponsors lectures, open to the public, on a broad range of topics.

The growing interest in laws concerning water rights, both private and public, has caused State and Federal Agencies, universities, private companies and lay organizations to initiate studies and to prepare publications on the subject. As it developed plans for the seminars to be given during the 1966-67 academic year, the Executive Committee of the Institute felt that the matter of legal problems was so important that four lectures should be devoted to various aspects of this topic.

Four outstanding individuals, representing diverse backgrounds and interests, agreed to participate in our program. The first lecture, "Legal Contributions to Water Resources Development" was given on October 19, 1966 by Dr. F. J. Trelease, Dean, College of Law, The University of Wyoming, Laramie, Wyoming; the next lecture, "Role and Problems of a Public Agency in Administering Water Legislation"', was given on November 16, 1966, by Mr. J. J. Curry, Chief Engineer, Connecticut Water Resources Commission, Hartford, Connecticut. The third, "Water Legislation - The Industrial Viewpoint"' was presented on December 14, 1966, by Mr. I. Laird Newell, President, The Henry Souther Engineering Company, Hartford, Connecticut, and the final lecture, "Altering a System of Water Rights - Look Before You Leap', was given on January 18, 1967, by Mr. W. M. Champion, Assistant Professor of Law, University of Mississippi, University Park, Mississippi.

The legal profession can indeed make important contributions to the proper use and development of our water resources. As Dr. Trelease pointed out, "The function of law is to regulate the relations between men or groups of men. In playing this role the law serves essentially a dual purpose. It provides a mechanism, the lawsuit, for the solution of conflicts after they have arisen, and it furnishes a guide - the rule of law, for the ordering of future conduct."

Appreciation is extended to the four speakers not only for their excellent talks but also for agreeing that their lectures could be published as this special bulletin of the Institute.

\author{
William C. Kennard \\ Director \\ Institute of Water Resources
}




\section{LEGAL CONTRIBUTIONS TO WATER RESOURCES DEVELOPMENT}

presented October 19, 1966 by Dr. F. J. Trelease, Dean, College of Law, University of Wyoming, Laramie:

A lot of water has gone over Connecticut's dams since I used to spend vacations as a child at Stony Creek and Madison. Practically all of my adult life has been spent in the mountains and plains of the west. My knowledge of eastern, and Connecticut, water problems consists only of a few second hand generalizations. What can a westerner contribute toward the solution of these problems? The westerner has always lived with water shortages, with conflicting demands for what water there is. Conflicts, if not literal shortages, are now appearing in in the east. I will give a short description of western water law, and let you find in it what you can that may be of value to you.

First let me say a work about the function that the law performs in water resource development.

The function of law is to regulate the relations between men or groups of men. In playing this role the law serves essentially a dual purpose. It provides a mechanism, the lawsuit, for the solution of conflicts after they have arisen, and it furnishes a guide, the rule of law, for the ordering of future conduct. The general goal of all law has been stated by John Dewey, the philosopher, who describes the law as "...a plan for organizing otherwise independent and potentially conflicting energies into a scheme which avoids waste, a scheme allowing a maximum utilization of energy." Roscoe Pound, the great student of jurisprudence, expressed much the same thought in this way:

"What we are seeking to do and must do in a civilized society is to adjust relations and order conduct in a world in which the goods of existence, the scope for free activity, and the objects on which to exercise free activity are limited, and the demands on these goods and and these objects are infinite. To order the activities of men in their endeavor to satisfy their demands so as to enable satisfaction of as much of the whole scheme of demands with the least friction and waste has...been what law makers and tribunals and jurists have been striving for..."'

By and large, the law at any particular time and place represents the will of the majority for encouraging action deemed desirable by them and for dis- couraging or forbidding action thought to be in conflict with the public interest. By encouraging some actions, but discouraging others, a state may use the actions of individuals to reach its own desired goal. There are few laws that are self-executing in the sense that they control all conduct and leave no choice of action to the individual. Much law does not literally regulate conduct in the sense of requiring or forbidding certain action, it instead provides an area of free choice, setting outside limits within which a person may act as he chooses. Many of these laws, such as those relating to property and contracts, unobtrusively form the basic framework of our society.

Western water law follows this pattern. The goal of the state, in adopting the law governing the use of water, is to obtain the maximum benefits, both social and economic, from the use of the resource. The law is designed to permit people to do some things that will advance this aim, and to prevent people from doing things that would be contrary to the maximization ideal.

The water law of the 18 western continental states, including Alaska, is the doctrine of prior appropriation. Its two cardinal principles are that beneficial use of water, not land ownership, is the basis of the right to use water, and that priority of use, not equality of right, is the basis of the division of water between appropriators when there is not enough for all.

The history of this doctrine is a fascinating chapter in the story of the growth of American laws and institutions. At the midpoint of the 19th century the common law of waters had definitely crystallized into the law of riparian rights. At this same time, the doctrine of prior appropriation spontaneously developed in the west to meet the needs of pioneers who came to the vast open spaces in search of gold, land and homes. Although it has sometimes been attempted, by doubtful analogies, to trace the doctrine from rather obscure early preriparian. English law, or from the early Massachusetts Mill Acts, or from Spanish law, the people who originated the doctrine were not versed in these by-ways of legal learning. They were miners who crowded into the gold fields of California in 1849. 
Swarming over lands previously uninhabited, they took the gold with the tacit permission of the true owner, the United States. After a lawless period, the miners, essentially law-abiding people from the eastern and mid-western states, organized "mining districts" to create some semblance of order on the then ungoverned public domain. These de facto governments promulgated rules and adopted customs regulating mining claims, and of equal importance, the right to use water to wash the gold from the gravels in which it was found. They established essentially the same rule for ownership of mining claims and for the right to use water. This rule was known as prior appropriation-the law of the first taker. This law was soon adopted by the courts. In 1855 the holders of claims that lay far from a stream diverted the stream over to their diggings. The owners of later claims lower on the now-dry stream bed sued to require the stream to flow down in its natural channel. The Supreme Court of California, in deciding the case, rejected the common law rule or riparian rights, since neither party had any title to the land. The court, taking notice of the existing political and social conditions, held that customs of the miners which had become firmly fixed should be followed. Among the most important of these, it was said, was that of protecting the rights of miners who by prior appropriation had taken the water from its natural beds and by costly artificial works had conducted it for miles over mountains and ravines to supply the needs of gold diggers. The court quoted no precedents: there were none.

When permanent settlers took up land for agricultural purposes and recognized the need for irrigation, they adapted to their purposes the water law evolved by the miners. It was a doctrine especially well suited for a pioneering economy based upon the settlement of vacant lands. The first settler to come into a valley chose his land. If irrigation water was needed, he dug a ditch from the stream to his land. Whether his land was located on the stream or not was immaterial, since there was no one to object to his use of the water. The second settler to follow him into the valley had to respect the first settler's homestead and take second choice of the land, and he had to respect the first appropriator's right to the water and irrigate his lands out of what was left.

Let us look at this law of prior appropriation in a little more detail. While there are minor differences in each state, and much of the law is now statutory, these state statutes have a common origin and are fairly uniformly construed. Other uses of water, in addition to mining and irrigation, were recognized as useful and beneficial by courts and legislatures. Appropriations may be made for domestic use, since water is necessary to sustain the life and health of man. Cities and towns may appropriate water for municipal purposes, to supply the municipality and its inhabitants with water for domestic uses, irrigation of lawns and gardens, sanitary purposes and for use in shops, business establishments and factories. The use of water for sawmills and ore reduction mills were purposes for which early appropriations were allowed in connection with mining, and today water may be appropriated for any form of manufacturing or industrial use. The use of water for the production of electricity is everywhere recognized as useful and beneficial. Water has been put to many other uses, such as railway use, the production of steam, refrigeration, cooling, the manufacture of ice, and for fish hatcheries. In modern times, a new beneficial use, recreation, has come to the forefront.

Other aspects of the law of prior appropriation should be noted. The amount or size of the right does not vary with the amount in the stream. An appropriation is always stated in terms of the right to take a definite quantity of water. Direct flow rights are stated in terms of the maximum current or flow that may be diverted from the stream, storage rights are expressed in terms of the total volume of water that may be stored. In general, the amount of water that an appropriator is entitled to divert or store is measured by the beneficial use to by served, be the need for sufficient water to accomplish the object of the water appropriation.

The place of the use is not limited to the streambank, as in riparian law. With few exceptions, an appropriation can be made to use the water at any place where it is needed. Diversions out of the watershed have been permitted and protected from the beginnings of the doctrine of prior appropriation. Diversions have been made in one state for use in another.

The allocation of water among appropriators according to priority may need some explanation. On a typical western stream where there are many irrigators with water rights initiated at different times, there may be water for all while the mountain snowpacks melt and the stream is high. As the quantity of water decreases, during the dry summer, the diversion works of the appropriators are shut off in inverse order of priority. The last ditch is the first closed, and the earliest is never closed. The right of the senior appropriator extends both upstream and downstream. He may take water needed by a junior appropriator below him, while the junior appropriator upstream must permit the water to go past his point of diversion when it is needed to supply the senior rights. The burden of shortage thus falls on those with the later rights; there is no proration in times of scarcity. The amount that each appropriator is entitled to receive remains fixed, if there is sufficient flow in the stream to supply it, and the senior rights are supplied in full while the junior rights are shut off completely. But juniors do have rights. Junior appropriators who take water from a source that has already been partially appropriated receive the right to use such water as is not needed by the prior appropriators. The downstream junior is entitled to insist that the senior take no more than his appro- 
priation allows. An upstream junior may divert water for his own use so long as he releases the quantity needed by the senior and he may make substantial changes in the regimen of the stream so long as he observes the senior's fundamental right to the use of the water. For instance, he may use the water to produce power, or in some other nonconsumptive manner, and he may even take the direct flow of the stream to which the senior is entitled if he replaces it with stored water or substitutes water imported from another source.

An appropriation is private property, and in most states it can be sold or used by its owner at any place to which the water can be transported. Changes can be made not only in the place of use, but also in the point of diversion, type of use, time of use, or place of storage, But the privilege of 'making such changes is subject to the rule that a change must not injure the vested rights of other appropriators.

An appropriation is a property right subject to ownership, and like land, is usually held in perpetuity. However, the right may be terminated if it is not used. It may be abandoned if the appropriator ceases to use it with the intent not to resume the use, and most of the western states have statutes which provide for a forfeiture of the right if the water is not used for a specified period, which varies in different states from three to ten years.

So much for the law. That's not all of it, but it does give us a thumbnail sketch, which we may now analyze to see what part this law has played in conserving and developing the resources of the West. We may characterize it by saying that the states have worked out a law under which a person by his own actions may carve out for himself a private property right from a publicly owned asset. Let us see if we have attained the goal of maximum benefits that I stated earlier, whether this give-away of natural resources has in fact conserved and developed western water resources.

In the water rights field, the goal of maximum benefits could conceivably be reached by complete and autocratic state control of all water resources, but this would mean that all water users would be regulated at every step by state officials, a situation generally regarded as distasteful by Americans. It would mean that all decisions on who could use water, what purpose it could be used for, when it could be used, would be made by a bureaucracy acting in the best interests of the state, with only secondary attention to the interests of the individual. It would not allow for nor make use of the tendency of the individual to act in his own best interest. It would not fit into our Anglo-American background, traditions and institutions.

American institutions are for the most part based upon the theory that individuals with a wide range of free choice can make their own decisions within limits set by governments, that each will attempt to achieve the largest possible benefit for himself, and that the total result of all of this individual action will tend to produce maximum welfare for the state or nation. In essence, we in the West have treated water like land. The nation gave away its land also, yet who will say that the Homestead Act, under which the mid-western prairie and the "Great American Desert" have been turned into fertile farms, was a mistake?

In the western states the aridity of the climate and the scarcity of water were limiting factors on development from the start. Yet no planners prepared blue prints for its best use. Instead the water was simply given to any and all who would put it to a beneficial use. The miner used it to unlock the coffers containing the mineral wealth of the mountains and streams, the farmers turned the desert into rich croplands, the rancher took the water for stock water and to irrigate the hay with which he could feed his cattle through the winter, cities brought in supplies that enabled them to grow, railroads, power companies, manufacturers and other industries received the water that enabled them to operate. The pioneer westerners recognized that development in their private interests could also be development in the public interest. Water was used to produce wealth. The increase in the wealth of the citizens, the secondary effects of the resulting increases in their purchasing power in spending in the community, in employment, tax revenues, and in goods made available for use by others, increased the wealth of, and developed the resources of, the western states and of the nation.

Let's look at one feature of this law that some observers, but not practitioners, of water law have questioned. This is the definiteness of the water right in terms of priority and of quantity, which enables the appropriator to in effect build a fence around his water right, much as he fences his land to keep off trespassers. This is the feature that throws all of the burden of shortage upon the junior appropriator. Some have questioned this as undesirable, and asked whether the equal sharing of the riparian doctrine might not be better. Yet in its unique fashion this rule has led to maximization of benefits. In the West it was early seen that an equal share of water that was insufficient for all would lead to parceling out the waters in shares that were sufficient for no one. The rule of priority is not as harsh as it sounds. It guarantees a firm supply to all those for whom the supply is sufficient; and these people have been able to build an agriculture unmatched in stability in any place where dependence is placed on natural rainfall. What of the poor junior appropriators? This law has encouraged them to develop water resources as no other rule would have. If the law were based on the concept of reasonable sharing of a common supply, and that supply was not sufficient for all demands, legal competition, not economic competition would occur for the available free supply. The "owners" would fight for greater shares of the 
same water on legal, not economic grounds. But where the rights of the claimants can be described so as to differentiate the water to which each is entitled, and one water user is given a superior right that can be protected, the later users will have to spend money to develop water from alternate sources, instead of trying to persuade a court that they should be given some of the water covered by the earlier right. In the west this is what is done by describing the right in terms of priority and quantity of diversion. When senior appropriators had taken all of the dependable flow of the western streams, further development was inaugurated by junior appropriators who built dams to store spring floods, built larger dams that would store the supply of good years against future droughts, or brought water from long distances across or through mountain ranges from other basins where the supply exceeded the local demands. Although some over-development did take place, and some junior appropriators today have only "flood water rights", they adjust to this just as does the owner of marginal land. When water does come, it is a bonus. But for the most part, state and federal laws have provided organization and capital to firm up the supply, to reduce the physical insecurity of the junior right, and to give all water users a firm right in a firm supply.

Another question sometimes asked by observers of western water law is whether it was a mistake to give the rights in perpetuity. Suppose, they ask, that while irrigation agriculture may have been the best use of water in pioneer days, but today the water is needed by industry or a city? Should not the water be reallocated so as to produce the greater benefits today?

Of course it should. But this does not mean that the industry or the city should be allowed to go to some official or board and persuade him or it that they could make better use of the water, and that therefore the water should be taken away from the farmer and given to them. Again, let me use my analogy to land. Suppose today a farm on the outskirts of the city could be better used as a factory site or as an airport. Do we run the farmer off the land, on the grounds that he is making an inefficient and wasteful use of a natural resource? Not at all. The industrialist simply offers to buy the land, tendering enough money to make it attractive to the farmer to leave. The city does the same, though it has the additional power to condemn the land to insure its transfer at a fair price, if the farmer holds out for an exorbitant sum. This same process holds true for transfers of western water rights currently held by irrigators, when industrial or municipal uses are more valuable. If the industrialist or the city cannot pay the price, then by definition the transfer of the water to them would not produce greater benefits. If in fact it will produce greater benefits, the value to the purchaser is greater than the value to the seller, and the transfer can be made as in the case of the pur- chase of land. There is no reason to take the water without compensation, and impoverish the farmer, by destroying his investment and his expectation built on the farm as a going concern. In a few of the western states, there are some restrictions on the transfer of water rights, but for the most part it is a property right which can be sold like any other. The movement of water to its highest beneficial use is insured by economic forces, not by governmental intervention.

I would not want to mislead you into thinking that the modern western water law is $100 \%$ pure laissezfaire. Although the economic forces of self interest that lead man to get the most out of his environment and of the market where relative values can be compared, are the basic operative mechanisms of prior appropriation, as long ago as 1890 the State of Wyoming, under the leadership of its first state engineer, Elwood Mead (for whom Lake Mead behind Boulder Dam is named) recognized that there could be exploitation of water resources that benefited the individual but were not desirable for society as a whole. Mead invented the permit system of appropriation, under which an intending appropriator must go to a state official and receive a permit, which will be granted only if there is unappropriated water in the source, if the proposed use will not interfere with the vested rights of others or if the use does not threaten to prove detrimental to the public interest. Fifteen states now impose this public interest limitation on appropriators, and while these powers have been seldom used (since as we have seen most appropriations of water have been in the public interest) state officials have chosen from competing projects the one which promises the greater benefits, and have denied a permit for a small single purpose project that would make infeasible a large multipurpose project, or applications for projects that would have harmful side effects upon other water users or upon the public, or have issued the permits subject to conditions that will prevent such harm.

Of course, all of this is foreign to Connecticut. The riparian doctrine is the fundamental law of water in the eastern United States, and in this state. Riparian rights are a form of real property, a part of land law. It is the ownership of the land that gives the right to the use of water and the corresponding power to resist uses by non-riparians or excessive uses by other riparians. In older times the nature of the right was thought to be almost an absolute, the fundamental right of the riparian was to have the stream flow as it was accustomed to flow in nature, unimpaired in quality and undiminished in quantity. In more modern times we have evolved the reasonable use rule, and today the great majority of American states apply the theory that the fundamental right of the riparian is to the reasonable use of the stream, and to be free from unreasonable interferences with his use. This permits a substantial amount of diversion, and a number of different uses of water have 
received approval-domestic use, household gardens, livestock, irrigation, the generation of power, and almost any application of water that fulfills a need or desire of man, so long as it is reasonable and can be exercised with due regard to the rights of other riparians. It should be noted that under the riparian system, a city is not usually regarded as having riparian rights of reasonable use, yet it must derive its rights from the riparians, that is, the city must purchase or condemn the water rights of the riparians whose uses are hurt by the municipality's.

Some have criticized this doctrine as nonutilitarian. But the reasonable use rule is quite functional, and not even the older natural flow rule is properly subject to this criticism. It was developed in the past century, in the early industrial revolution, when water power for mills and factories was perhaps the principal use of smaller streams. The rule that streams should be left within their banks passed the water down from one mill dam to the next, and thus served the dominant elements of the economy. Modern industry has different needs for water, and today if an industrialist needs water for a plant, he can buy land on the river bank and procure his factory site and water right in a package deal. Up to now, the riparian right doctrine has worked quite well for the east, primarily because of the abundance of water. It is usually contrasted to the appropriation system as an alternate means of allocating water, but only a tiny fraction of eastern water rights has ever received judicial allocation. In actual operation, the law of riparian rights has permitted the large majority of the most logical water users to proceed freely, without restriction, and without friction or litigation. The legal processes of the lawsuit have been held in reserve, as a sort of a "fire fighting" mechanism for settling the few disputes that arise.

But I will guess that modern pressures of increasing population and increasing industrialization are putting quite a strain on the doctrine that served 19 th century rural populations and small industries quite well. As a basis for investment, riparian rights are an imperfect form of property. The flexibility of the reasonable use rule means that the water user will not always be protected from infringement of his use by other riparians who seek a reasonable share in the source. He does, of course, have a firm right which he may defend against non-riparian users and for which cities must pay. But a number of uncertainties beset him, and these could reach a point where investment is discouraged, or where location of factories is governed by availability of large quantities of unciaimed water, though this may add costs that produce no return, and thus be a departure from our optimization ideal.

Perhaps no feature of riparian law has received more adverse and critical comment than the concept that the waters are reserved for the benefit of the lands along the stream, and that rights to the use of water are special privileges of the owners of such lands. The obtaining of the maximum benefits of the use of water is a goal that is obviously not always reached by using it nearest its source. It is arguable that progress can be accommodated by sales and transfers of riparian lands with their attached water rights. This is an imperfect market, however, for in such a sale, the water right is removed one step away from the market. It is the land that is bid for, not the water. Yet, the land may be an unwanted burden imposing extra costs. Furthermore, the argument that these riparian transfers adequately provide for economic flexibility assumes a mobility of the enterprise that may not exist. A farmer desiring to improve his yield by irrigation cannot move his land to the river bank. A mining operation might need water for processing or at the mine mouth, and many other locational advantages such as access to raw materials and labor might require the water, rather than the enterprise, to be moved.

Riparian law is not very well suited to the transfer of water rights separate from the land. It is an even more imperfect form of property in its transferability and salability aspects. A riparian right cannot literally be sold as such to a non-riparian. All the latter can do is buy his peace from riparians. Perhaps water rights pass on the market in this crude sense, that the former use yields to the new in exchange for money. But the "grant" of the riparian right is regarded as binding only between the parties. It stops the grantor and his successors from complaining of the non-riparian use, but it has no effect against other riparians. A riparian with an extra large "unreasonable" demand that cannot be met because of an upstream "reasonable" riparian use might buy out that single riparian, but he would receive no assurance that others would not make similar demands on the freed water. A riparian with a very large use, or a non-riparian, might foreclose a lawsuit from a downstream riparian by buying him out, but thus closing the mouth of the trouble maker would give no assurance that others would not step in to make objections.

I would like to suggest that a more serious charge lies against riparian rights as a basic system of water law. It allocates the water to riparians-private individuals who own property. But the public has many non-ownership demands on water-recreation, including fishing, swimming, boating, etc.-uses that involve no withdrawal from or damming of the stream. They are protected only in "public" waters-traditionally limited to navigable waters, and for the most part navigable waters receive a restricted definition that limits protection of such public uses to only the largest streams. The public has other interests, for although many of these privileges attach to private riparian rights, much public use of private waters still takes place.

The public has many interests other than recreation that may be harmed by private uses of water, and such private uses are frequently accompanied 
by "spillovers" (no pun intended), external effects that harm others or impose "social costs" on other persons. Riparian doctrines, enforced in two-party law suits, are not very good vehicles for protecting the public interests. Nor are market transactions in water and water rights. Purchase and sale are not very efficient methods of allocating water to public uses, since the public is often widely dispersed and each individual has so small an interest that there is little incentive to take legal steps to protect public rights or even to join hands into an effective group for economic protection of public rights or to purchase water for public use from the private interests who hold the water rights.

What is needed is public control of the inception of water uses. In allocating rights to use, public regulation may take the form of restricting the uses for which rights will be granted, restricting the persons who may acquire rights, and restricting the rights granted both in scope and duration. Undesirable uses should be prevented from ever arising, not stopped after the harm is done. Uses prima facia beneficial which entail substantial possibilities of unfavorable effects may be conditioned to permit the good and eliminate the bad. One of the most important aspects of controlling the initiation of uses is the power to deny uses, to reserve the water for more desirable purposes. The power to deny permits for uses that involve diversion from, or interruption of, a stream is also the power to reserve water for use in place, usually by the public. In this fashion the most effective protection can be given to site values, recreation values and fish and wildlife habitat.

Similarly, water use laws of this nature could play an important role in the current major problem relating to Connecticut waters-pollution control. Water quality is a function between water quantity and the load of pollutants carried. A new use of large quantity of water, upstream, that depletes the flow, holds back the flow, or transports the flow across a divide may change downstream discharges of effluents from tolerable levels to intolerable pollution. Laws may be needed to control withdrawals so as to leave minimum flows in the streams, dams may need regulations requiring them to store water for release during periods of low flow in order to maintain the minimum flow for transportation and dilution of sewage and wastes, where full purification is impossible or too costly.

Today, at least seven eastern states have statutory controls on riparian uses. They require permits for the exercise of riparian rights much like western appropriation permits. The water officials use this device to control water use and to prevent public harms. Two states have substantially adopted the western law of prior appropriation and permit the water to be used where needed, and no longer require the water to be used on the river banks. Several other eastern states have adopted statutes permitting persons who store water to use the stored water with- out regard to riparian law.

The law of underground water forms a somewhat different pattern. Ground water seemed so unlike water in streams that historically it was treated differently. The first rules were of ownership. The landowner was regarded as owning the water underneath his land, and was permitted to take whatever quantity he could capture. A number of state courts then imposed requirements that the owner's use of ground water must be reasonable, and related to the overlying land. Primarily, this rule protected rural users from the cities which invaded the countryside to obtain large supplies of well water. A few states have applied a rule of correlative rights similar to riparian doctrines of reasonable sharing. Many eastern states have superimposed substantial statutory regulation on the exercise of these common law doctrines. A number of western states now have statutes adapting rules of prior appropriation to ground water, and attempt to hold withdrawals to some concept of the safe yield, and to regulate mining of unrecharged ground water.

Connecticut has one large river that drains only a small part of the state, and many small coastal streams whose branches cover the rest. It is a thickly populated industrial state, yet one with a good deal of agriculture and much gracious countryside. Apparently, in the past, too little thought has been given to one problem, water quality, so that today corrective cleanup of the streams is the major necessity. Let me ask how much better the situation might have been if a really effective pollution control law had been in effect in the beginning. And let me ask if the same reasoning does not today call for a law regulating water withdrawals and use, rather than letting these processes proceed to the point where real conflicts and problems arise and will require expensive corrective measure.

Let me suggest some of the problems which may arise in Connecticut, for they have long existed in the West where water is short and they are occurring with greater frequency throughout the eastern states. Growing cities find themselves dependent on streams and aquifers that are inadequate for present and future demands. New industries determine their location on the factors of availability of land, transportation and labor, and find that water is more flexible and can be supplied from afar. Farmers look with envy on their neighbor's irrigated riparian fields, and seek for their lands this form of weather control. Rural residents abandon their individual wells and seek some form of central rural water distribution organization.

Engineers find physical solutions for these problems. They pump or divert large supplies from available streams. They make transbasin diversions from some nearby or even faraway watershed more generously supplied or with smaller demands. They build dams to equalize flows throughout the seasons of the year, or the flows of good and bad years. They 
inject stored or transported water into existing wellfields, recharging dwindling supplies of ground waters with surface water.

But these solutions create other problems. In Connecticut one real one would be the legal one-the water rights of the diverters, storers and importers might be tenuous and insecure. Other problems are practical-large diversions or reservoirs may inflict harm on prior users. They may impair fishing and recreational, even scenic and historical values. They may affect, quality control, as I mentioned earlier. Property owners might be affected by reservoirs, not only from direct flowage, but also by the effect on site values of fluctuating water levels.

A good comprehensive water use code could make an important contribution to Connecticut at this time, and insure that the development of her water sources would proceed along desirable lines. It will be argued by some people that since Connecticut's water resources are quite large, and since so little of her streams are presently being used, there is now no "need" for a water law. But if Connecticut waits until serious disputes arise, if legislation is delayed until emergencies demand it, people will be hurt. Expensive and unnecessary litigation will arise, uncertainties will be created, investments will be lost. Wyoming enacted the first effective water use regulation law in 1889 , Alaska the newest in 1966. Both states were at the time young and undeveloped, but their laws are blueprints for development. Nor is the abundance of water a reason for not taking action. Mississippi, which has between 50 and 60 inches of rainfall per year, now has a complete appropriation water code similar to the western models.

In states where a "wait and see" attitude has prevailed, the pattern has often been a haphazard and piecemeal treatment of particular water problems, urged by persons with special interests who are able to capture the ear of busy legislators. Such legislation can be unfair in its preferential treatment of particular activities and disregard of other groups with similar or opposite interests. It can actually hinder overall economic activity more than it helps. In particular, the interests of the public have too often been forgotten is such piecemeal legislation. On the other hand, in states which have considered the overall problem, a comprehensive water code has proven to be a most effective way of encouraging economic growth. Such a code permits all the various water-related activities to grow at their own speed, and in their own direction but always with some consideration for other activities and interests.

Such a code should not impose unnecessary and burdensome restrictions on industries or the people. It should permit the acquisition of private property rights in water, secure enough to encourage development and flexible enough for economic forces to change them to better uses, and subject to public regulation only when private economic action does not advance the public interests. It need not take the form of pure western prior appropriation. Many different forms of law could accomplish these objectives. Connecticut's law might preserve and build on cherished institutions, local practices, and comfortable old phrases. But legislation giving administrators and judges rules and principles that will aid people to take steps toward obtaining maximum benefits from water resources, using the initiative of private enterprise, and imposing regulation only to protect interests of the public and prevent harm to others, would surely set Connecticut's footsteps toward the ultimate goals of the law and the obtaining of maximum benefits from her water resources. 


\title{
ROLE AND PROBLEMS OF A PUBLIC AGENCY \\ IN ADMINISTERING WATER LEGISLATION
}

\author{
presented November 16, 1966 by Mr. John J. Curry, Chief Engineer, Connecticut
}

Water Resources Commission, Hartford.

The topic "Role and Problems of a Public Agency in Administering Water Legislation" when first assigned did not reveal itself as being as meaningful as it proved upon further consideration. So I will have to credit Professor Kennard for the assignment of a topic so worded by chance or design that it led me to develop several points that I can present for your consideration today. It appears to be the ordinary type of program wording which most representatives of public agencies would attack with an overloaded enumeration and explanation of the problems faced in their specific area of administration. The main objective of such an approach would be to evoke sympathy for the speaker in the performance of duties for which he is generally adequately paid. I have followed this tact on occasion and probably have been able to acquire a reasonable share of the listener's sympathy.

This title, however, places the role of the public agency before its problems and it makes one realize that the problems create the role. Today I will try to develop the role of our agency in a modern Connecticut society. This role arose from the necessity of handling the problems of water inherent in our historical development. If it be a necessity that the role be designed so as to handle such problems, an understanding of the role should make enumeration of the problems unnecessary.

The humid temperature climate of Connecticut is surprisingly similar to the maritime climates enjoyed by residents of the British Isles and Western Europe. Naturally there is a correlation between our attitudes on the relation of waterways to private property. In such climates it is difficult to define an ownership of a parcel of land of any respectable size without having it border on or contain within its boundaries a watercourse. The waterway is not a unique property in itself but is merely an essential element in the value of the land. One's rights in the land naturally included rights in the waterway. The water, however, differs from the land in being mobile. It provides its value to more than one parcel. Actually part of its value is this mobility. If all property owners are to enjoy this item of the property value, the water in the watercourses must be allowed to run in its wonted manner. The property owner and the community develop if the property is maximized by developing its appurtenance, the water. If the land owner makes any reasonable use which does not affect the flow to a neighbor in quantity or quality the value to each land parcel should be maximized. Inherent in this utopian theory are two converse realities. First, that the value of one parcel could be increased to the loss of another parcel if an unreasonable use of the water were undertaken; and secondly, that the parcel depreciated might not have any use for the right misappropriated.

It is true that most cases in law considered the physical use of the water, the changes of regimen or volume of flow or the elevation of the water surface. However, just as valid within the definition is an unreasonable use which adversely affects the chemical quality of the water itself. Such quality can be affected by processing the water or by discharging into it other water dissimilar in character. For this second type of unreasonable use, it appears that adjoining parcel owners were either less affected or less interested in protecting their rights. In Connecticut by the end of the 19th century many serious depreciations in the quality of our waters existed presumably because affected property owners had not sought redress against unreasonable uses.

This general disinclination to defend one's property against this type of invasion existed in spite of a thoroughly friendly attitude of the courts toward such appeals as were actually made. The extent of the court's inclination to preserve property against unreasonable water use is illustrated in a very important decision in 1895 against the City of Danbury. Even though the polluter in this case was a city which was acting for a public purpose, under an authority of law, and in the exercise of its governmental duty and not withstanding that the damage to an individual resulting from such public action would be small, the court maintained that the common interest required any riparian to exercise and enjoy his rights in the waters of a running stream in such a reasonable manner as not to injure unnecessarily the rights of any other owner.

Because the general public as well as the riparian parcel owners has an interest and is affected by the 
depreciation of water quality it was apparent that Government must act to protect the common rights. As in all such matters the first approach of the public to exert its rights is through its representatives in the Legislature. In 1886, the public used the legislative method in its simplest form, namely: to pass a prohibitive statute. This statute prohibited the City of Meriden from carrying out a plan to discharge its sewage into an adjacent waterway and led to the construction of the first sewage treatment plant in the state in 1891. As the problems became more numerous and more complex, the approach of legislative action by a simple prohibitive statute was no longer practical. A broader approach through legislative action was obtained by passage in the General Assembly of an act to establish a Commission to study the problem. This was done in Connecticut in 1897. Subsequently, when there was a permanent agency of the state, the State Board of Health, who could carry out such investigations, the Legislature in 1913 directed a study by this operating administrative group rather than a special Commission. In a still later action, the Legislature realized that the problem of industrial waste was somewhat outside the ken of the Board of Health so it provided an advisory board to help the regular agency investigate this type of pollution. Such committees and their successors finally concluded that it was necessary to have a permanent administrative section of the State Government to protect the general public interest in all matters having to do with pollution either from sewage or industrial waste. The Water Commission which was the predecessor of the present Water Resources Commission was established in 1925, being one of the first such legislative acts on these matters in the Country.

The role of the Water Resources Commission, therefore, is one that has developed step-by-step from the proliferation of problems of the unreasonable use of waterways by one riparian to the detriment of other riparians or the general public. Few cases have been referred to the court or to the Legislature since the establishment of the administrative agency. The Commission apparently has taken over these problems and has to a satisfactory degree protected the affected interests.

Only an administrative agency can perform the role because fundamentally it arises from problems of such number that they cannot be satisfactorily handled by legislative or judicial action. The role is played in two parts. The first part is to prevent or to discover and eliminate unreasonable uses. This is a complex engineering problem and can only be handled by an accumulation of skill and experience applicable to this specific business. Other administrative agencies are necessary because skills in other disciplines are required. For instance, the special skill of accounting would be necessary to control banking operations. Certain skills in biology would be necessary to develop Fish and Game Re- sources. Certain skills in botany or husbandry would be necessary to control agricultural development. But in the Water Resources field the necessary skill is that of engineering even though ultimately associated basic sciences are helpful and necessary. Only an engineer thoroughly skilled in the manner of handling water and the methods of alleviating or eliminating undesirable parameters of quality can answer the question of whether a specific use is reasonable or whether it unnecessarily restricts the reasonable use by others.

The assimilation and proper handling of all the actions which would have had to be taken by affected riparians or established public or private interests is a major and important task related to fundamental property rights. Once assumed by the state it must be thoroughly performed. There must be an arm of the Government or at least a finger of the Government which educates to prevent many problems which would arise; which negotiates to prevent or ameliorate a problem which has arisen; which directs the correction when a problem has arisen in spite of negotiation; or appeals to court when the directive for correction has not been honored. In all of these steps a considerable technique based on the engineering knowledge is necessary. Even the referral to court which might appear to be a simple action of sending the file to an attorney, requires technical witnesses to help present the case, and the accumulation of the technical file which supports the case.

It should be noted in Connecticut that besides our work in negotiations and direction, we have taken the ultimate enforcement steps on many cases. Several actions have gone through Superior Court and appeals have gone to the Supreme Court. Several cases involving large municipalities have gone to contempt citations. These actions in number and importance probably exceed the efforts of any other state in this field.

The second part of the role is to develop feasible methods and economic means by which riparians can make an ever increasing use of their water rights without detriment to others. These methods and means are the mechanical and structural devices that allow scientific knowledge to be used. It means a continuous development and improvement of Connecticut's techniques and current knowledge of improvements in the art by others. This then, to protect the property rights and to develop methods to eliminate the need for such protection in spite of increased use, is the two part role of a public agency in the pollution abatement field of Water Resources management. All the current problems which could have been enumerated come from the necessity of performing these technical functions.

A very pertinent example of the operation within this role is provided by the current work of the Water Resources Commission resulting from certain de- 
mands by the public for improvement of water quality as expressed through the Clean Water Task Force. This expression of the public desire clearly indicates that the public anticipates a water quality which can only be achieved through the treatment of all discharges by so-called secondary methods or better. It so happens that the science of pollution abatement has been developed by others, with a definite contribution from the State of Connecticut, so that these methods are today well known even though a few years ago they were not common. Also at the present time Connecticut has achieved a couple of decades of experience in the operation and the evaluation of different types of such secondary plants and has gained the necessary experience in the special handling of these effluents for further refinement. Because of this continuity of experience Connecticut is prepared to carry out the desire for stream qualities resulting from these kinds of treatment.

In the early days of the operation of a pollution control agency in the state, little was known of methods of treating industrial waste to a similar degree. The Connecticut agency through projects at Yale and Wesleyan and to a lesser extent at this University researched these problems and developed some of the basic methods. Although such work is now largely done in better funded projects of the Federal Government and the larger states who entered the business later, we can agree with the statements of the Clean Water Task Force that there are methods available for the satisfactory treatment of the industrial wastes found within the state. To be in a position at any time to protect against what the public currently identifies as unreasonable uses, the state must maintain, in being, an administrative agency with a continuity and background in the engineering aspects of the pollution abatement problem. It is, I believe, a corollary that such a role could not be carried out by any other Governmental process.

If we can go far afield from pollution abatement, but stay within the area of Water Resources management, I believe that we can make similar points about the administration of flood protection measures. One would suspect by the amount of material that has recently been published on the subject that most of the country has suddenly realized that the elimination of flood damage is much more of a problem than the mere construction of flood control works. Recent compilations have shown that the annual flood damages are increasing despite the fantastic investments in such water control structures. If the Federal Government or the states which operate flood control programs had allowed the problems to define their role such a realization would have been achieved sooner.

Beyond the construction of control works the other part of the problem of reducing flood damage is administrative control and although it is now getting its full recognition nationally, the development of this concept in the State of Connecticut was parallel to the achievement of administrative control of water pollution. Here again the role of an agency such as the Water Resources Commission in this field arose from the development and proliferation of real problems. Once again we must start by recalling that because we have a humid temperature climate, we have high annual rainfall. It follows that we can also expect short-term periods of excessive rainfall.

One of the uses of a water right accruing to the riparian parcel is the opportunity to realign the watercourse or to build a dam so as to change the elevation of the water or its natural regimen of flow. This again is a proper use if it is reasonable and does not effect reasonable uses by other riparians. The Mills Act provided for compensation to allow more extensive water uses of this character beyond the rights connected to a single parcel. However, rules of compensation generally applied only to normal conditions. Adjacent riparians were not inclined to protect themselves against injury only related to rare periods of flood flow. Floods were relegated to the category of "Acts of God" and without property owners acting to protect themselves, many uses had accumulated in Connecticut by the beginning of the Twentieth Century that would be proven unreasonable at the time of a flood. The state did experience floods of considerable magnitude in 1927, ' 36 , ' 38 , ' 49 and twice in 1955. These experiences uncovered and exposed the real problems of flood control damage.

Theoretically, a riparian either alone or with a neighboring parcel which adjoined at the center of a stream could produce a total obstruction to the flow. The unreasonable character of such an obstruction, a dam, could be easily identified and protection against or compensation for obtained by the upper riparian owner unreasonably affected. However, lesser obstructions, encroachments, the detrimental effect of which would be recognizable only during the short duration of periodic high flows were placed in great numbers particularly in locations of high property values throughout the State. Hundreds of encroaching structures such as bridges were placed for public purposes and with public funds. Successive parcels using these structures as indicators one after the other maximized their value at the expense of the waterway. Each development being equally reprehensible chose not to defend itself. When the floods came a large share of the property losses to these parcels were diverted to the public. Control by a government agency was necessary to define what kind of flood was reasonable to consider in making waterway encroachments and to determine what kind of encroachments would be unreasonable for such a flood.

After the ' 38 floods the state expressed an interest in the construction of water control structures, but it was apparent by the late 1940's that the pub- 
lic also wished to consider the problem of keeping the waterway channels open so that they could carry a reasonably anticipated flood. Again the first step was through the Legislature. It provided individual municipalities the authority to establish lines along the streams beyond which riparians could not encroach. However, this authorization of an extension of their powers was not used to any degree by municipalities.

After the '55 flood, the Legislature in facing the flood problem had to consider why it had not been used. In the first place few of the streams of concern were within confines of one or two municipalities. There would be difficulty in setting a reasonable system of restrictive lines if it were not done in neighboring communities at coincident times. Secondly, it was also apparent that the setting of such lines depended on the engineering capability that could not be anticipated in a municipal office organized to solve more ordinary day to day problems. Undoubtedly, there was also the realization that such property restrictions were not handled easily within a local political situation. At least an action by a state agency would be more uniform and detached.

The Legislature, therefore, directed that the Water Resources Commission should establish such lines. The definition of the program desired by the Legislature was not entirely clear from the wording of the Act. Little specific direction was given to the agency probably because a Legislative body does not have the necessary assistance to delineate such a technical problem. They did, however, in their deliberations, indicate the results they wished to obtain by administrative control, to maintain a highway to the sea for flood waters. It was also apparent that they were talking of alleviating all problems from floods such as 1955 or in other words, large floods.

Taking this rather vague directive, it was the job of the Commission to adopt an operating procedure for all watersheds so that all riparians throughout the state should receive equal treatment. First, a system had to be developed based on past experience to develop floods of similar character for all watersheds. Luckily in controlling the safety of dams, a technical computation had been devised which was admirably suited to provide this criteria flood for all watersheds whether they had been gauged or not.

The lines, of course, must take into account existing conditions. A theoretical symmetrical channel would not be a satisfactory basis for a restriction on property use. The lines must be based on the actual flood water elevation. The lines must also be capable of location on the ground so that future arguments about the compilation could be easily settled. The techniques for determining what types of structures would be permitted within the lines must be stated.
To work under these general concepts, the Commission developed a set of policies and procedures to clearly define to the general public what was to be accomplished by the legal restriction. These policies and procedures became so common in usage and so satisfactorily understood by the general public and those specifically affected, that they were capable of being written into the statute by a subsequent Legislature.

Once again we see the role of an administrative agency in water resources as being one which through continuity and experience sets up engineering know-how to solve problems of private riparian owners and the general public and assumes the responsibility of protecting their rights. It seems apparent also that no part of Government except an agency for the administration of engineering concepts could perform such a function.

A similar review could also show that our agency's work in administering the control of safety of dams or the regulation of structures in navigable waters are roles that developed to solve problems of general public rights or rights of property owners which because of the manner of development had become too numerous or too vague to be handled individually.

However, if we confine our consideration to pollution abatement and flood control we direct our attention to the phases of water resource management primary to our kind of climate. In other climates matters such as public water supply or crop irrigation might be the major problems which have to be solved.

As I understand your program for this semester the four seminars planned will provide a variety of viewpoints on water law. It may be presumptuous of me to express opinions in that field. My father who has derived an ability of colorful metaphor from long experience in human relations described one public figure by saying there is damned little he does not admit to knowing. Assuming a like attitude for a moment I would ask you to keep in mind the more or less orderly development of the role of our existing water resource legislation when seemingly logical arguments are made for radical changes.

Recommendations for radical changes are generally made on the assumption that existing systems have proven inadequate to cope with a problem. If this be the reason then its degree of truth should 'se verified before further consideration. Is a system nadequate if it has provided control of encroachment along hundreds of miles of our major streams, and has provided treatment of 96 per cent of sanitary wastes almost a third of which is high degree of treatment, and provided treatment for over 50 per cent of our industrial wastes, and has maintained 95 per cent of our streams and shoreline free of pollution at a cost to the state of less than $\$ 100,000$ per year? If these results are unsatisfactory then we should consider whether it is better to act more aggressively under the existing system or find a new and better 
one.

One used to risk the onus of blind conservatism in this field when he did not advocate new approaches. Nowadays there are so many suggestions being made that one is unique and radical when he is not promoting what are assumed to be new concepts. However, not all change is improvement even when the immediate result may seem wholly desirable. Remember the case of the fellow who was married for thirty years and his wife never knew he drank until the day he came home sober.

If we consider the possibility of using the theory of prior appropriation in an area where the prime problem is pollution or flood control we must consider whether the appropriator's rights shall include the right to pollute the stream as well as divert it or whether it includes the right to encroach if the only damage is to the community and not to a prior user.

Of course we might conclude that we could better solve our irrigation problems under such a theory and pass particular legislation against pollution. However, there are few irrigation problems to solve and such pollution control legislation would not have the firm basis of our present approach. More important though how would such fiat legislation allow the flexibility of ever increasing the use of our waters by the improvement of treatment methods so that new uses can become reasonable. Since pollution is what the general public presently finds undesirable, administrative control that is tied directly to basic rights should always be on sounder grounds than a mere technical description of a current political desire. Even a law prohibiting adultery can appear to be a nuisance restriction unless it is based on the public necessity of preserving the social structure of families to alleviate unbearable police and social service costs.

Once again does the one who places an unwarranted encroachment gain the right under prior appropriation? One would suppose that a restriction statute could prevent such uses. But, if the right is real property, can the appropriator be deprived without due compensation? The court has agreed that the prevention of an unreasonable encroachment by a riparian is a proper use of the State police powers.

It is sometimes pointed out that the quality of water could be improved by purchasing a flow to di- lute pollution. We noted that there are practical systems available to treat all the wastes in Connecticut to provide the quality of water desired. Dilution instead of removal is dodging the problem and as a method must eventually limit development of waterusing industries. Not even in a humid climate is water sufficient for such a use. Structures often are suggested to delay the ultimate stifling, but these are generally attractive because they offer the possibility of diverting some of the costs to the public. In any case it violates a simple basic principle that President Johnson recently found necessary to reiterate, "No one has a right to pollute."

It is sometimes pointed out that the public under appropriation doctrine could garner by purchase or prior claim a flow to improve fishing or other recreational uses. Under our present system the public needs only to become a riparian owner to achieve such use presuming no other is making an unreasonable use.

It will be more and more realized that in our region, in our climate, and in our society an important use of small waterways is to add to the value of our land in a strictly esthetic sense. We like to experience a running stream or a still pond. Water is part of our landscape as much as our rock outcrops and our rolling hills. The old mill dam or its modern reproductions has the same significance as expansive lawns or wooded glens. How does one appraise the importance of such an esthetic use against a productive appropriation? Could any one afford to enjoy such uses?

There are of course answers to all of these questions. I am sure you either know them or will soon hear them and it is not within the intent of this paper to carry out the complete dialogue. It is suggested that in appraising the answers one might consider whether the questions ever need to be raised and one might remember that ours is a land of many steep, small streams, not one of widely spaced large streams.

At least, in considering the legislative definition of the role of a water resources agency make sure that it is based on the problems which we must solve to continue our development at an ever increasing rate. 


\title{
WATER LEGISLATION - THE INDUSTRIAL VIEWPOINT
}

\author{
presented December 14, 1966 by Mr. I. Laird Newell, President, The Henry Souther
}

Engineering Company, Hartford, Connecticut.

\section{WATER LEGISLATION THE INDUSTRIAL VIEWPOINT}

The title of this paper is a very broad one, and while we are interested in Connecticut in the laws pertaining to our own area, it will be necessary to discuss somewhat the background leading up to the statutes now governing our use of water and the competition now developing for the use of water as well as the technology which is being developed at the same time.

The natural water purification cycle, rainfall, runoff, evaporation, was known over 2,000 years ago and given in the Old Testament, Book of Ecclesiastes, Chapter I, Verse 7.

"All the rivers run into the sea;

Yet the sea is not full;

Unto the place from whence the rivers come,

Thither they return again."

The distribution of the world's water is as follows:

$\begin{array}{lc}\text { Oceans and Inland Seas } & 97.2 \% \\ \text { Icecaps and Glaciers } & 2.15 \\ \text { Liquid Fresh Water } & 0.63 \\ \text { Atomospheric } & 0.001\end{array}$

It is apparent that if fresh water withdrawn for use could be discharged to the oceans far enough from the continental shores, treatment of waste water would not be necessary. However, since our populations are not entirely located within reasonable distances from oceans and our water use is approaching the maximum fresh water available from natural sources, it is apparent that waste water must be reused and fresh water conserved.

The fresh water is made up of ground water, lakes, rivers and streams, and water in surface soil. The volumes are roughly as follows:
Ground Water
(less than $1 / 2$ mile deep)
Ground Water
$1,000,000$ cubic miles
(more than $1 / 2$ mile deep)
Lakes
Surface Soil
Rivers and Streams
$1,000,000$ cubic miles
30,000 cubic miles 16,000 cubic miles 300 cubic miles
It is apparent that our lakes and streams have only a small amount of water compared with the reserves which are present underground, and this may be one

of the reasons why so much attention is being given today to underground water resources.

The figures given in the table above represent a static condition but we, as users of water, are more interested in the rate of replenishment of the fresh water.

In the United States, the water resources replenished by precipitation vary from season to season and location. However, the national average precipitation is about 30 inches per year. The average precipitation for Connecticut is about 43 inches per year. About $70 \%$ of the precipitation, on the national basis, returns to the atmosphere by evaporation or transpiration. The remaining 9 inches, or $30 \%$, is the potential supply 1 .

On the basis of volume, the total income from precipitation in the United States is about 1,430 cubic miles. $70 \%$ of this, or 1,000 cubic miles, returns to the atmosphere by evaporation or transpiration. Stream flow accounts for about 390 cubic miles going directly to the oceans, leaving about 40 cubic miles unaccounted for. It is believed that this loss is underground flow to the oceans. Converting some of these results to gallons shows the following:

\begin{tabular}{|c|c|c|c|c|c|}
\hline Tational Rainfall & 4,3 & illi & llo & er & \\
\hline Runo & 1,200 & " & " & ", & \\
\hline Withdrawn for Use & 26 & " & " & ", & " \\
\hline Water Consumed & 62 & $"$ & $"$ & " & ", \\
\hline led with $W_{\varepsilon}$ & $\mathbf{s} 20$ & ", & " & " & , \\
\hline
\end{tabular}

The total dependable supply for the United States in 1980 is estimated at 515 billion gallons 1 . In a report on Waste Management and Control recently published by the Committee on Pollution of the National Academy of Sciences, they have projected, for the year 2000 , that 890 billion gallons, representing twothirds of the total stream flow, will be returned to the rivers in a polluted condition.

In our state, the per capita consumption of water may range from 80 to 120 gallons per day, and engineers commonly use 100 gallons per capita for design of water systems. The total United States usage of water is at the rate of 1,600 gallons per person per day. The big difference is, of course, that used by industry. To make a ton of rolled steel requires 110,000 gallons of water. A ton of synthetic rubber requires 660,000 gallons of water. To make a loaf of bread, grow the grain, process and bake, requires 
500 gallons of water; thus, the industrial use far exceeds that of domestic use. From a survey made in 1962 of the metal industry, including metal finishing which in Connecticut is one of the major types of industry, the following table shows the water use: Million Gallons per Year (Connecticut)

New Water

Water Recirculated

Total Water Usage

Water Discharged

Water Consumed

It is apparent that before the year 2000 , the competition for water will be so great that recovery and reuse from wastes will be commonplace, and conservation of new water controlled by law.

In the last few years the public has been educated to the need for legislation to control the use and prevent misuse of water. Since industry is the major user, any legislation will be important in planning the future course for any manufacturer. Federal and state statutes as well as local ordinances now control to a large extent both the sanitary and industrial wastes of a manufacturer.

While both federal and state legislation pertains to municipal, individual, as well as industrial problems, they are nevertheless treated differently at the present time. As an example, in a town where there is no municipal sewage treatment plant, or sewer system, an industry must construct, at its own expense, facilities for sewage disposal. No grants, either federal or state, are obtainable at the present time for such construction.

\section{FEDERAL STATUTES}

In urging passage of the Federal Water Quality Act, President Johnson said "From the Androscoggin to the Apalachiocola, from the Susquehanna to the Snake, from the Kanawha to the Klamath, every major river system is now polluted." The Water Quality Act of 1965 was signed into law on October 2 and is known as "P.L. 234, 89th Congress." The policy is given as follows:

"Section 1. (a) The purpose of this Act is to enhance the quality and value of our water resources and to establish a national policy for the prevention, control, and abatement of water pollution.

"(b) In connection with the exercise of jurisdiction over the waterways of the Nation and in consequence of the benefits resulting to the public health and welfare by the prevention and control of water pollution, it is hereby declared to be the policy of Congress to recognize, preserve, and protect the primary responsibilities and rights of the States in preventing and controlling water pollution, to support and aid technical research relating to the prevention and control of water pollution, and to provide Federal technical services and financial aid to State and interstate agencies and to munic- ipalities in connection with the prevention and control of water pollution. The Secretary of Health, Education, and Welfare (hereinafter in this Act called 'Secretary') shall administer this Act through the Administration created by section 2 of this Act, and with the assistance of an Assistant Secretary of Health, Education, and Welfare designated by him, shall supervise and direct (1) the head of such $\mathrm{Ad}$ ministration in administering this Act, and (2) the administration of all other functions of the Department of Health, Education and Welfare related to water pollution. Such Assistant Secretary shall perform such additional functions as the Secretary may prescribe.

"(c) Nothing in this Act shall be construed as impairing or in any manner affecting any right or jurisdiction of the States with respect to the waters (including boundary waters) of such States."

This act authorized $\$ 150$ million per year for the next two years for use as construction grants to municipalities. Up to $\$ 1.2$ million is authorized for a single project which controls pollution. Unfortunately, private industry is not eligible for these grants, but industrial waste treatment plants built and operated by a municipality are eligible. Canham, editor of the Journal of the Water Pollution Control Federation, Washington, D. C., has interpreted this Act in a recent article $(2)$ :

"1. The governor of a state or a state water pollution control agency has the opportunity to file within a year (by October 2, 1966) a letter of intent that the state, after public hearings, will, before June 30,1967 , adopt (a) water quality criteria applicable to interstate waters or portions thereof within the state, and (b) a plan for the implementation and enforcement of the water quality criteria adopted. If the Secretary of HEW believes that these criteria and plans are acceptable in accordance with the definition established in this Law, these criteria and this plan shall become the applicable water quality standards.

" 2 . If a state does not (a) file a letter of intent, or (b) establish water quality standards as outlined above, or if the federal government or a state desires a revision in the established standards, the Secretary of HEW may, after reasonable notice and a conference of appropriate federal, state, interstate, municipal, and industry representatives, prepare regulations setting forth the water quality standards.

" 3 . If standards are prepared and published by HEW as outlined in the latter portions of (2) above, the state has six months to (a) adopt standards suitable to HEW, or (b) petition for a public hearing under the procedure outlined in the law. The hearing is conducted under a complex arrangement but will be convened in or near the affected area. The hearing board will be composed of five or more persons appointed by the Secretary of HEW. Each state affected may select one member and other affected federal agencies may select one member each. There may not be a majority of members who are 
employees of HEW.

"If the hearing board approves the standards prepared by HEW, they become effective immediately, or the Secretary will modify the standards in accordance with the Board's recommendations at which time they become effective.

" 4 . If the state does neither of the alternatives outlined in (3) above, the Secretary of HEW shall promulgate the standards discussed in (2) above.

" 5 . If violations of the established standards are detected the Law provides for court action (after a notification to the violators of at least six months prior to the initiation of any abatement action) in one of the following ways: (a) in case of pollution in a state other than that in which the discharge originates the Secretary may request the Attorney General to bring suit, or (b) in case of pollution within a state and the damage is confined to that state, the Secretary may, with the written consent of the governor of the state, request the Attorney General to bring suit.

" 6 . If a suit is brought to court, the standards as well as the alleged violation are given court review.

"7. The provisions for enforcement as contained in the former Law are continued in the new Act. This allows the Secretary, at the request of or in concurrence with the governor or other state or local agencies, to institute the conference and hearing sequence leading to the same court procedure. Presumably, after June 30,1967 , the procedures added for the new Law will supersede in practice the use of this section since standards then become the motivating factor."

All of the states, including Connecticut, have already filed the necessary documents with the Federal Government, and water quality standards are being adopted. The New England Interstate Water Pollution Control Commission Standards of Quality as adopted September 14, 1966, are available from the New England Interstate Water Pollution Control Commission, 73 Tremont Street, Boston, Massachusetts. (10) These standards have been changed slightly from the 1959 standards and now include specific limits for coliform bacteria in Class $\mathrm{A}$ and Class $\mathrm{B}$ waters and specific limits for $\mathrm{pH}$ in all classes of waters.

Since the 1965 Water Quality Act, the control of water pollution has been transferred from the Department of Health, Education and Welfare to the Department of the Interior, and all of the functions of the Department of Health, Education and Welfare under the Federal Water Pollution Control Act have been taken over by the Secretary of the Interior. Included among these functions will be the sections of the Housing and Urban Development Act, the Applachian Regional Development Act and the Public Works and Economic Development Act, dealing with water pollution control. The 1966 Reorganization Plan for Water Pollution Control of Interstate Waters became effective May 6,1966 . (11) The policy of this Reorganization Plan is given as follows: "It is the policy of the Department of the Interior to carry out the Federal Water Pollution Control program in a manner that will achieve high standards of water quality in the Nation's rivers, lakes, streams, estuaries, and coastal waters. The Federal Water Pollution Control Administration shall mount a vigorous program of prevention, control, and abatement 'to enhance the quality and value of our water resources'. The Administration will function as one of the major units of the Department and other bureaus and offices within the Department shall consult with the Administration on all matters within their program areas related to water pollution control. Pending the approval of an interdepartmental agreement to implement the consultations provided for by subsection $2(k)$ of the Water Quality Act of 1965 (79 Sta. 905), consultations shall be carried out with the Department of Health, Education and Welfare on the health aspects of the program. All existing relationships of the Administration with the States and their water pollution control agencies and with interstate agencies shall be preserved." In addition, this plan states: "No standard will be approved which allows any wastes amenable to treatment or control to be discharged into any interstate water without treatment or control regardless of the water quality criteria and water use or uses adopted. Further, no standard will be approved which does not require all wastes, prior to discharge into any interstate water, to receive the best practicable treatment or control unless it can be demonstrated that a lesser degree of treatment or control will provide for water quality enhancement commensurate with proposed present and future water uses."

Since the transfer of the pollution control administration to the Department of the Interior, there has been a departmental agreement between these departments established September 2, 1966. (12) The Health, Education and Welfare Department is to give to the Department of the Interior recommendations on water quality criteria based on health aspects, technical assistance in connection with water pollution control, review and comments on construction grant applications, and also conduct studies on health aspects of water pollution.

\section{STATE STATUTES}

In Connecticut, the control of water and wastes is given to two separate departments. One, the State Department of Health is a single agency and operates under the General Statutes of Connecticut Section 19-13. As part of the statutes 3 , the Public Health Code, Chapter 2, Environmental Health, gives to the Health Department control over nuisances including industrial wastes and sewage. In particular, Sec. 19-12-B1, B2, B3, B8, B20, B22 and B50 pertain to industry. Of particular importance is Sec. 19-13B22 - Manufacturing and other wastes:

"No materials or waste products from any mill, factory, slaughterhouse, rendering or fertilizing 
works, junk establishment, common carrier or other industry or utility shall be stored or deposited so as to cause the surrounding atmosphere, land or water to be contaminated or polluted in such a manner as to injure the public health or create offensive conditions."

The other agency responsible for the control of water and wastes is the Water Resources Commission which consists of seven members appointed by the Governor. One member is to represent the manufacturing interests. This Commission operates under the General Statutes of Connecticut, Sec. 25. These are the most important from the industrial viewpoint and those pertaining in particular to industry are the following: Section 25-19, 25-20, 25-21, 25-22, 25-23, 25-24 and 25-26."

The Commission has the authority by law to establish standards of quality for rivers and streams. They may, in accordance with Sec. 25-21, order a person, firm or corporation to build a treatment plant to control pollution within limits established by them provided the cost of construction and operation by the method specified is not unreasonable.

The Commission may order a person, firm or corporation to have an engineering survey made prior to making an order so that the cost of construction and operation.may be established.

Sec. 25-23 deals with new sources of pollution and prevents a firm or corporation from creating any source of pollution not existing in 1925 without first obtaining a permit from the Commission. Any substantial change in character or volume of the pollution existing before 1925 is considered a new source.

Examples of stream classification in Connecticut are the Housatonic and Connecticut Rivers. It will be noted that the Connecticut River at the Massachusetts State line is now Class D and is to be upgraded to Class C. From Hurd Park to Saybrook Point, the river is to be upgraded to Class $\mathrm{B}$. The Housatonic now Class $\mathrm{C}$ is to be upgraded to Class B.

The Water Resources Commission has another very important function - that of allocating Federal Funds established specifically for pollution abatement. At the present time, no federal or state funds are available to be granted to industry, but any municipality may construct and operate a pollution abatement plant for industrial wastes and be eligible for federal funds. The Town of Wallingford has constructed and operates such an industrial waste treatment plant for the use of industries in Wallingford.

It would seem not only feasible but desirable for towns or municipalities to construct treatment facilities in newly established industrial parks, be eligible for Federal Grants and have control of the operation in the hands of the municipality rather than the industry. While it would be expected that industry would be taxed and pay for the operation on a strength and volume basis, the capital investment would be paid for by the town aided by state and federal grants.
Another important Connecticut Statute is Sec. $12-81$, subsection (51) which exempts water pollution control facilities constructed after July 1, 1965 from taxation by the town in which it is located.

\section{FUTURE LEGISLATION}

We have reviewed the water legislation as it now exists, but what of the future? Many committees, industries, commissions and branches of government are presently studying and getting together data for the writing of new legislation. The results of some of these studies are given in reports available to the public.

A survey of "Water in Industry" by the National Association of Manufacturers and the United States Chamber of Commerce 4 reviews the availability of water for industry, the methods and costs of waste treatment and the legal regulation of pollution. It is stated that industry in 1959 spent more than $\$ 100 \mathrm{M}$ to operate waste treatment plants and that the replacement cost of the facilities would be more than $\$ 1$ billion. They recommend an informed public "that can participate constructively in reaching decisions that will always have to be made in the fields of water resources and pollution."

In a seminar on "Water Pollution Control"5 during the 30th Chemical Industries Exposition, Barco, et al gave a paper on "The Timetable for Federal Control of Water Pollution." They conclude in part:

"Direct federal concern and control over national pollution is no longer a possibility - it is a growing reality with a mandatory timetable for execution. This reality is a consequence of the joint concern of Congress and the Executive, backed wholeheartedly by the general public and communications media. It is a wide-ranging fact of life with which industry and civic communities must learn to live, and a legal responsibility and moral challenge which must be effectively met."

Many representatives of industry have appeared before committees and subcommittees of the House and Senate, and the views expressed will undoubtedly influence future legislation. F. E. Tucker of the National Steel Corporation, gave the following in part to the Senate subcommittee on Water Pollution: "We find it difficult to understand how it can be in the public interest to supply federal financial support for municipal pollution control, but against the public interest to suggest federal tax relief for nonrevenue-producing industrial pollution control equipment. We are told each phase is of equal importance to the public good. By the same token, each deserves equal consideration."

A. J. von Frank of the Manufacturing Chemists Association, before the Muskie Subcommittee, indicated that a $7 \%$ or more tax credit and depreciation of construction costs in one year would be desirable.

Many others have also indicated that industry requires assistance by means of direct grants, investment tax credit or fast writeoff to pay for nonrevenue- 
producing investment in the field of water pollution control. A number of proposed bills will allow tax writeoff in from 1-5 years. A one-year writeoff is equivalent to classifying the capital expense as an operating expense and thus fully tax deductible.

Studies are now being made for legislative bills covering federal grants for joint industrial-municipal treatment plants and other bills are being written to provide research and demonstration plants.

Merwin E. Hupfer, Principal Sanitary Engineer, Connecticut Water Resources Commission, in his paper "Survey of Federal Aids" 6 given at the November 1966 meeting of the Institute of Public Service, The University of Connecticut, reviewed recent federal legislation. Hupfer stated, in referring to the legislation passed by Congress just before adjournment, "The bill provides funds (if subsequent Congresses appropriate the money) as follows: $\$ 450$ million in Fiscal Year 1968; $\$ 700$ million in 1969; $\$ 1$ billion in 1970 ; and $\$ 1.25$ billion in 1971 - a total of $\$ 3.4$ billion for the four years of which Connecticut anticipates receiving about $\$ 47,000,000$. The bill also allows prefinancing of federal grants by states or municipalities. With the new provisions federal participation will be as follows:

"1. $30 \%$ of any construction project, regardless of cost.

" 2 . $40 \%$ of any construction project to which a state contributes at least $30 \%$.

" $3.50 \%$ of any construction project to which a state contributes at least $25 \%$ if the state also agrees to impose quality standards on navigable intrastate streams.

" 4 . $10 \%$ increase in grant to any project that is part of a metropolitan area-wide plan.

"If the 1967 General Assembly adopts legislation as proposed by the Clean Water Task Force and the President signs the new Federal bill, grants of $70 \%$ and possibly up to $85 \%$ will be available. The Water Resources Commission's intricate priority rating system and limitation of $\$ 250,000$ per project, developed to disperse Connecticut's meager grant allocation among our municipalities in the most equitable manner possible, can be abandoned. Thus, Connecticut's municipalities would have all the financial incentive necessary to construct their needed sewage treatment works facilities well within the time schedule recommended by the Clean Water Task Force."

Other committees in the Federal Government are also promoting attacks on pollution. The Subcommittee on Science, Research, and Development, aided by Connecticut's Emilio Q. Daddario, has recently submitted a report on "Environmental Pollution" to the Committee on Science and Astronautics of the U. S. House of Representatives. 7 Their conclusions are given in part as follows:

" 1 . The pollution problem is composed of two related concepts: the kind of natural surroundings we want and need; and the cost and means of obtaining these qualities. The hearings testimony demonstrates that there are inadequacies of knowledge in both areas that are frustrating the further definition of the problem and that are barriers to abatement progress.

" 2 . Considering the powerful forces for ecological change which are at man's disposal, admitting the impossibility of complete fore-knowledge of the consequences of many activities, and granting that a highly technical over-populated world must continue to take risks with natural resources, an 'early warning system' for unwanted consequences is extremely important. We do not have such a system at present.

" 3 . Other than in the case of gross and obvious pollution, there is insufficient information to set ultimate objectives, criteria and standards. The directions of improvement are usually clear enough so that near term objectives can be set in terms of percent reduction. But short of the unrealistic zero point, few limiting conditions or ultimately allowable concentrations can be specified on a scientific basis. Nothing about the testimony suggested that present legislation had gone beyond the existing technological basis. But the urgent and insistent nature of the Clean Air Act and the Water Quality Act is a strong stimulus to R. \& D. to provide more knowledge and better techniques.

" 4 . Firmly established criteria and standards for environmental quality are necessary to give industry a basis for planning and action. Only then will the science and engineering resources in the private sector be fully motivated. These skills and facilities are needed to solve internal corporate problems, and to meet the market demand for abatement processes and techniques which enforcible standards will generate.

"5. Therefore, the immediate research needs are in (a) improved abatement methods for gross and obvious pollution, and (b) ecological and human health data for criteria and standards setting.

"Any large and rapid expansion of research and development will have to be performed to a great extent in the private sector (with contracts and grants if necessary) because Federal laboratories and personnel cannot expand fast enough. However, some considerable capabilities, which would be applied to pollution, exist in Federal research centers established for other primary missions.

"6. Federal Government scientific activities are not yet channeled to support announced goals in pollution abatement. There is no organization or coordinating group capable of systems analysis and broad management of Federal projects. Insufficient funding has made support of research spotty and disproportionate among problem areas. Agency missions may inhibit long term and comprehensive ecological studies. 'Pollution' can cover an enormous variety of Federal agency programs ranging from water resources research to agricultural engineering. Limitations of definition will be necessary for effective program coordination.

"7. Technical manpower will be a limiting factor 
in abatement progress unless additional effort is organized into retraining, graduate education, and transfer of skills from other technology programs.

"8. Ecology, as an organized profession, is not in good condition to become the umbrella for increased research. As a scientific discipline it is the logical focal point. As a point of view it is already effective in coordinating other sciences and this may be the most important function in the long run.

'9. Complete solution of pollution problems may not be possible, but two trends are discernible. More recycling of materials is a way of managing and eliminating wastes as well as a sound conservation policy. The impact of recycling on the economy can be lessened by imaginative product and process design. The other trend is the controlled transport of unusable wastes to some sort of perpetual safe storage. The use of ocean depths, deep wells, salt domes, burial, and caves needs careful study to assure that there are no undesirable effects on the biosphere from such disposal.

"10. Large scale demonstration of new and improved abatement methods will be necessary to establish efficiency and costs. Massive city-sized experiments, freed from the inhibitions of present institutional practices and investments, are the nature of research in urban ecology. Government funding in an underwriting or risk-sharing role is justified to move technology from the development stage, through demonstration to wide application.

" 11 . The interactions of Federal science funding with industrial research resources is quite different in pollution from those relationships in the military space programs. The Federal Government is not the major customer for the products and processes resulting from R. \& D. in pollution. Industry may be alert to its responsibilities but Federal research support will be needed to stimulate development of abatement methods to show when standards can be met and to bring improvements in a timely manner. Beyond these points, abatement technology should be in the control of normal commercial enterprise."

\section{FUTURE STATUTES IN CONNECTICUT}

In Connecticut, a Clean Water Task Force was appointed by the Governor in October 1965 "to study the pollution problem in Connecticut and recommend the best, quickest, most efficient and economical way to eliminate it." This Task Force completed its work and provided a report entitled, "Clean Water for Connecticut - An Action Program." 8 The specific recommendations of this report cover a 7-year plan for pollution abatement of Connecticut's waters as follows:

"Step 1 A state bond issue, of $\$ 150$ million, to be authorized by the 1967 session of The Connecticut General Assembly, to finance a greatly accelerated program of waste treatment.

"Step 2 A revision of state business taxes which pertain to the treatment of industrial wastes.

"Step 3 A general review of all state laws and codes which pertain to the use of water, as well as a study of how these laws and codes can best be administered by our state government.

"Step 4 A vigorous support of Federal Pollution Control Legislation."

Industry will be most interested in the recommendations of Step 2.

"Industrial waste is another major source of pollution in Connecticut's water. Whenever the treatment of industrial waste cannot be included in new or enlarged municipal treatment plants, industry must be assisted in the construction of their own treatment plants. To prevent industry from being taxed for non-productive investment the State should allow a one year write-off for waste treatment plants.

"Also, the State Sales and Use Tax should be revised to exclude materials bought and used in the construction and operation of industrial treatment plants, this revision to become effective during the calendar year 1967 .

"Also, industries which must relocate within the state, in order to treat their wastes adequately should have access to redevelopment funds.

"Here again, while the cost of treating industrial wastes is considerable, it is not prohibitive. Moreover, like municipal waste, the job can be done. There is no form of industrial waste in Connecticut which cannot be treated with methods and techniques now in existence.

'Industry is the backbone of Connecticut's economy. We must be willing to share the cost to industry of this seven-year program to clean up the water they must have to survive."

They also recommend an upgrading of the state laws and codes which pertain to the use of water, and their report recommends not only wide changes in existing laws but new legislation to cover both municipal and industrial pollution.

"The present laws under which Connecticut must operate in regard to the use of water are clearly obsolete. Indeed, it is a tribute to the State Water Resources Commission, that, under present law, and with such inadequate financing they have been able to operate at all.

"The Riparian Code, upon which our laws are based, was developed during the time of the Romans! It was satisfactory for a sparsely settled frontier society but it does not apply today. Connecticut will have a population of $5,000,000$ by the year two thousand. It seems doubtful that any municipality, any industry, or any individual should have the 'right' to pollute water. Therefore, our laws and our codes which pertain to the use of water must be updated.

"The State should retain the burden of proof to show pollution. 
"The State should not be required to prescribe specific methods of waste treatment.

"The State should have the right to seek redress in court against any polluter who has not complied with an order.

"The polluter should have the right of appeal on the grounds of legality or equity.

"A long range plan must be developed which will set guidelines for improving the quality of water for an ever expanding population. This plan must take into consideration the public water supply, water for industry, agriculture, recreation, and the propagation of fish and wildlife. It must also be coordinated with planning activities for all New England.

"Since new requirements will be placed upon them, the organizational structure of the Water Resources Commission and the State Health Department must be studied. Their staff should be increased."

I would recommend that every industrialist study not only the report of the Clean Water Task Force, but should also study the review of the requirements proposed by the Task Force by John J. Curry, Chief Engineer, Water Resources Commission, given as a paper at the November 3rd meeting of the Institute of Public Service, The University of Connecticut. 9 The new legislation as stated by Mr. Curry will present "requirements that it is apparent must be carried out by the Water Resources Commission because there is no one else who can perform them and the general recommendations resulting from such an expenditure of effort by the Task Force cannot just be left on the table."

As a final comment, I would like to state that as recent as 5 years ago, I would not have felt any real urgency about our pollution problem, but today I feel we should go forward as fast as our resources will permit. By this I mean manpower as well as money.

by

\author{
I. Laird Newell, President \\ The Henry Souther Engineering Co. \\ Hartford, Conn.
}

Presented at The University of Connecticut Water Resources Institute December 14, 1966

\section{BIBLIOGRAPHY}

1. "Water" - Bureau of Mines Preprint from Bulletin 630 - 1965 U. S. Department of the Interior.

2. Robert A. Canham - "Status of Federal Water Pollution Control Legislation" - Journal Water Pollution Control Federation - Vol. 38, p. 3 (1966)

3. The Public Health Code of the State of Connecticut July 1964

4. "Water in Industry" - National Association of Manufacturers (1965) - 277 Park Ave., New York City

5. "Water Pollution Control" - Chemical Industries Exposition Seminar - Published by Southwestern Engineering Co., 6111 East Bandini Boulevard, Los Angeles, California

6. "Survey of Federal Aids" - Institute of Public Service, The University of Connecticut, Nov. 3, 1966, by Merwin E. Hupfer, Water Resources Commission

7. "Environmental Pollution" - A Challenge to Science and Technology Report of the Subcommittee on Science, Research, and Development to the Committee on Science and Astronautics, U. S. House of Representatives published by the U. S. Government Printing Office, Superintendent of Documents.

8. "Clean Water for Connecticut - An Action Program" - Department of Agriculture and Natural Resources, Hartford, Conn., July 1966

9. "Requirements Proposed by the Clean Water Task Force" by John J. Curry, Water Resources Commission - Institute of Public Service, The University of Connecticut, Nov. 3, 1966

10. The New England Interstate Water Pollution Control Commission - Water Use Classes and Standards of Quality for Interstate Waters September 14, 1966. Available from office at 73 Tremont St., Boston, Mass.

11. Water Pollution Control - Reorganization Plan No. 2 of 1966. (Prepared by the President and transmitted to the Senate and the House of Representatives in Congress assembled, Feb. 28,1966 , pursuant to the provisions of the Reorganization Act of 1949, 63 Stat. 203, as amended).

12. Interdepartmental Agreement between Health, Education and Welfare Department and Department of the Interior in accordance with Reorganization Plan No. 2 of 1966 


\title{
ALTERING A SYSTEM OF WATER RIGHTS - LOOK BEFORE YOU LEAP
}

\author{
presented January 18, 1967 by Mr. W. M. Champion, Assistant Professor of Law,
} University of Mississippi, University Park.

\section{ALTERING A SYSTEM OF WATER RIGHTS - LOOK BEFORE YOU LEAP}

By William M. Champion*

The topic assigned this writer is that of making the transition from one system of water rights to another. This was done in Mississippi in 1956, when we changed from the riparian doctrine to one embracing many of the concepts of the Western doctrine of prior appropriation. Because only those who have studied Connecticut's water problems in detail are qualified to recommend which system of water rights should be adopted in this state, I propose to approach the subject as generically as possible. To this end I shall direct my attention to three areas of consideration - law, policy, and administration. The title of this paper, Altering a System of Water Rights - Look Before you Leap, is perhaps a bit misleading if not explained. It is not the writer's intention to point out numerous pitfalls that await anyone making the change, nor to advocate a policy of "Go Slow" or of no change at all. Rather, the main purpose is to present certain matters that should be investigated before you settle upon what course shall be followed. This is based on the experience of the past ten years in Mississippi. Some of these things were done, and some were not done. Therefore, this author has the advantage of hindsight.

\section{BACKGROUND}

In 1952-1954 Mississippi suffered from what we consider severe drouths. Several representatives of various economic interests, led by Delta cotton producers, began to question our system of water rights. Crops were dying or stunted, and investments in irrigation equipment looked attractive, but only if a firm system of water rights protected these investments. Manufacturers and other commercial users of water began to express concern over the increased demands being made on our streams. Accordingly, an inter-agency organization consisting of representatives of about a dozen various economic interests, ranging from the Farm Bureau Federation to the
Mississippi Economic Council - the state chamber of commerce - was formed to study water supply and needs, and to recommend remedial legislation. With assistance from the United States Soil Conservation Service, in 1956 this organization recommended to the legislature a law applicable to surface watercourses, which is patterned largely on the Western system of prior appropriation. This passed with little difficulty.

\section{LAW}

In an earlier meeting of this seminar Frank Trelease briefly explained the basic systems of water law. However, for the benefit of those who missed that session, and to refresh the memories of those who attended, I will briefly state these doctrines.

The doctrine of prior appropriation applies to the use of natural watercourses in eighteen of the nineteen western states, including that tier of states from Texas to North Dakota, and all west of them except humid Hawaii. Riparian rules also apply in some of these states. Riparian rules are extensively followed in some of the thirty-one eastern states. Humid Mississippi is a notable exception. Connecticut is a riparian state, with the doctrine having become established during the salad days of water power, when hydro-electric plants were unknown, and mill ponds accounted for the bulk of on-stream impoundments.

The basis of the riparian doctrine is a co-equal sharing of the water in a stream, although domestic uses normally are given a preference. This sharing is not participated in by all who need or can use the water, but generally is limited to those who own land contiguous to the watercourse. However, riparian rights to use navigable watercourses may be subject to public rights of way for commercial navigation. In several states, public rights of use may include pleasure boating, fishing, swimming and the like.

Finally, one of two rules will determine how much water may be diverted by riparian landowners. The first of these is the "natural flow" rule, which provides that each riparian is entitled to have the 
water flow onto his lands undiminished in quantity and quality. This means that a user cannot materially alter the natural flow of the stream. The other rule is the "rule of reasonable use". This means that the use to which the water is to be applied must be reasonable in the light of all surrounding circumstances, such as method of use, nature of use, quantity desired, quantity available, and other demands for the water. In actual practice there may be little difference in the end result of the application of the rules.

Prior appropriation - the code of the west - is quite different. Contiguity to the stream is immaterial, and the basis of the right is "first come, first served". Water rights are normally expressed in terms of maximum quantities diverted at maximum rates of diversion. Thus, the appropriator senior in priority - time of initial use - may continue the full exercise of his right even though there be insufficient water to satisfy all appropriations. In this event, the junior appropriators must cease their diversions of water. Insofar as total stream depletion is concerned, most jurisdictions afford no protection to the flow of non-navigable streams, and those which do provide only for a limited continued flow.

The type of use ordinarily is not limited so long as it is regarded as a beneficial and non-wasteful use. Thus, Mississippi recognizes seven types of use ranging from domestic to recreational, and including the rather indefinite category of "other" uses. Some western states accord a higher preference to some uses than to others. In Mississippi only domestic users are given such a preference.

This is about as brief a coverage of the two basic water rights doctrines applicable to surface watercourses as is possible, but with the foregoing features in mind let's look at our problem.

A word of caution is due here. The mere establishment of a firm system of water rights is not necessarily a panacea for water problems. All the lawyers and lawmakers in New England can't effectuate a good water program unless they are aware of what they hope to accomplish, understand the problems - physical and political, present and future with which they are dealing, and obtain laws that will insure the reaching of their goals. A bad decision could be worse than no decision at all.

\section{POLICY}

What is the fundamental policy behind a system of water rights? The choices here are several, but a clearly defined selection should be made before passing any law regulating water uses.

The basic policy, in turn, is dependent upon the problem or objective. Here in Connecticut, and other northeastern states, the problem has had at least four aspects. There are periodic shortages of water. Admittedly your rainfall greatly exceeds that of most western states, but eastern water utilization economics have previously dictated different uses and methods of use, as well as different reservoir systems, than those employed in the west. Therefore, an extended drouth as we easterners know it, puts water reserves in danger.

Second, most eastern states have problems of distribution. While we have high average annual rainfall, it does not always fall when we need it, and entirely too often it rains when we would rather not have it. Furthermore, the water won't cooperate by sitting around in a convenient place until needed. Instead, it runs off into small streams, then larger and larger ones, until it is far from where it fell, and from where it is needed. Thus, although we have lots of water, we don't necessarily have it where or when we need it.

Everywhere in the humid east one encounters wasteful uses or methods of use of water. Traditionally, riparians have been reluctant to police their stated prohibitions against waste, and certainly no one would consider violations of them even as misdemeanors. Yet, untold billions of gallons of water are wasted annually through the employment of outdated industrial equipment and processes, overuse of water, inefficient municipal water and sewage systems, and simply giving water away.

Finally, the entire nation is faced with pollution. Streams in every section of America are polluted, but because New England is so heavily industrialized, pollution problems here seem to be more acute than is true elsewhere.

These are a few of the particulars of your water problem. They have in common two features. First, they are not uniquely Connecticut or northeastern problems. Therefore, the rest of us will benefit from the experience of whatever decision you ultimately make.

The second feature is that each of these problems is characterized by some aspect of limited availability of usable water. It might be said that this water shortage problem is, in some aspects, an easy problem. It is easy because it is readily identified. The solution may be difficult, but at least you know what you're working with. In the east, however, this is not the entire problem. Here there is more ground water, more lakes and ponds, more watercourses, and more rains than is true in the west. As continued misuse of water forces easterners to give it a higher economic value, they will clean up the streams, build the necessary reservoirs and transportation systems, and prohibit waste to the end that the shortage will be at least temporarily alleviated.

So the eastern problem is more nebulous. It involves an ascertainment of the value of water at a time when we still tend to treat it as a free good. Second, there must be found a way to realize the full value of a resource so precious that men have defended their rights to it with firearms. This is difficult in an area that historically has considered flood control and drainage as its greatest water problems. This writer doesn't have the answer to this problem, but it is submitted that, it must be con- 
sidered when forming a tasic policy. Thus, Connecticut's policy should grow out of the solutions. to at least two problems - periodic water shortage, and failure to significantly capitalize upon one of the natural advantages held over other sections of this country, and, indeed, many parts of the world.

What will be the ultimate objectives of this policy? Many alternatives are available. It can be a stop-gap policy designed merely to provide some insurance to some users in times of shortage. Many support this type of measure and characterize it as a "firm system of water rights". This is the system largely employed in the west where, due to their arid climate, it is more than merely a stop-gap policy, but apparently is the best yet devised. In humid Mississippi, however, it would appear that it is nothing more than a predetermination of relative rights to be employed in the rare instance of water shortage. While this is good in that it minimizes the necessity of periodic litigation, it does little to prevent water shortages, or to stimulate greater utilization of a normally abundant water supply.

A policy designed to merely restrict inefficient uses of water, or to guarantee certain preferred users their supply could be adopted. In that case, you might inaugurate a limited permit system, under which users for designated purposes must obtain a permit. Then, when water is in short supply, these permittees may be outside the riparian doctrine, and will be either allowed to continue their full use or required to cut back or terminate their diversions, depending upon whether the system is designed to protect or restrict them. Clearly such a system can promise only limited achievements, because the policy has limited objectives.

There are other short-range policies that may be considered. These would include guarantees of municipal supplies, water for industry, and recreational attractions. However, with approximately 30 inches of rainfall in 1965, 34 in 1964, and 37 in 1963 , plus a twenty-year average in excess of 40 inches, Connecticut is in a position to develop a comprehensive and fully integrated water regulatory system containing many of the features previously mentioned.

A comprehensive and fully integrated system is first one that provides security in their rights for those that the state has decided should be protected. These might include domestic users, municipalities, irrigators, industrial users, recreational interests, or any other categories that mind might conceive. The system should not only secure their rights, but should define their standing in regard to each other as competition for water increases. In the event the system does not equally secure the rights of all categories of users, then it should provide a clear method of resolving conflicts among the lesser protected users.

Second, the system provides sufficient flexibility for the convenient evolution of water use patterns. Thus, it should remove the limitations of the concept of riparian lands, so that water might be trans- ported beyond the site of diversion or withdrawal to the place of ultimate use. Then, it should make water rights freely alienable with no loss of priority - or dignity of right - occasioned because of a change in the ownership of the right or the place of its exercise. Finally, on the point of flexibility, the system can aid in reaching the goal of maximum benefits to the community by basing the comparative dignity or strength of competing rights on method and type of use, rather than one who used it first. While the relationships of small children may be satisfactorily governed by the cry of "me first", this is not a particuiarly sophisticated way in which to allocate such an important natural resource as water.

Third, the system includes all uses of water diversionary and nondiversionary, consumptive and nonconsumptive, and may well include pollution control. This means "control" and not "abatement". It would seem that in the proper situation, controlled pollution can be equally as legitimate a use of water as is irrigation or the creation of hydro-electric power. An industry employing hundreds of persons with an annual payroll in the millions may return a greater benefit to the community than would numerous farms. Now, if there is insufficient water for both the absorption of effluent and diversion for irrigation, which should be allowed? In the proper circumstances, pollution within approved State and Federal standards may be allowed on the same basis as are diversions.

Fourth, the system includes all water activities of the State. Therefore, the State should look into the inclusion of drainage, flood control, reservoir systems and improvements to navigation as part of its overall system. This is the master water plan as has been developed so fully in California. Connecticut's development would not follow theirs, nor be nearly so expensive, because your problems are quite different. Nevertheless, with a policy so broad, you can insure a reasonably adequate supply and manage this resource so as to minimize losses of unused water to the hydrologic cycle.

Finally, the system includes both surface and ground water. Furthermore, it recognizes the actual distinctions and inter-relationships between them. Where ground water is in reality a part of the flow of the stream, it should be treated accordingly. Where it has no relationship to surface water, perhaps a different allocative system is in order.

This is an outline of what the author considers to be five essentials of a comprehensive fully integrated water rights system or policy. As one can readily see, much of it deals with features other than individual rights. This is necessarily so because water use and water supply management are inseparable, as are water law and economics, and water economics and social policy. None of these disciplines can function in the abstract, but all must relate to each other and to the many other disciplines that may come into play. 


\section{ADMINISTRATION}

Let's now direct our attention to the administration of a new system of water rights.

At the outset it should be stated that the system is no stronger then the state's willingness to police it. This means money. The law in Mississippi may be fundamentally sound, but because our administrative agency is too short-handed to police it, there are untold violations of the law each year. Now if this is of no consequence, it would be safe to assume that the law is either unnecessary or in the wrong form. Thus, if the state isn't willing to police the law, then possibly it would be best to make no change.

Regardless of its form, the administrative agency should be given at least quasi-judicial powers. Colorado employs the system whereby each water right is adjudicated by a court. They like this. However, a more streamlined and efficient method is to have the agency adjudicate the rights, with its decisions subject to appeal within a prescribed period of time.

This introduces the first big problem of administration. Qualified personnel are hard to find. The agency should have someone experienced in water problems who can combine a working knowledge of engineering, law, and economics with administrative ability and judicial temperament. Mississippi has been extremely fortunate to have the services of such a man. However, many who appear qualified probably could not handle his job.

The form of the agency was mentioned earlier. Mississippi has found a policy-making commission headed by a chairman that oversees the work of a professional staff headed by an executive officer to be most satisfactory. This allows for the day-to-day functioning of the agency under the direction of its leader, but subject to the policies and regulations of a body primarily devoted to that aspect of the total operation.

Once personnel have been selected, the next big problem will be the sudden influx of work. The Mississippi Board of Water Commissioners has acted on approximately 1,250 requests for water rights in the past ten and one-half years. Over 1,000 of these were acted on in the first two and one-half years following the passage of our law. The reason is that most of these water users were already engaged in using water. They filed almost immediately, and thereafter new users appeared rather slowly.

This problem is particularly acute when the responsible State agency is just getting organized, because many of the personnel are new, many policy decisions have not been made or even considered, and everyone may have his own interpretation of the law. In this regard, it would be most advisable for the Attorney General to assign someone from his staff to become proficient in water law and to work with and advise the responsible agency.

The final big problem of administration that has been encountered in Mississippi is money. Our pro- gram falls far short of the fully integrated system previously described, yet each biennium the Board of Water Commissioners must accept an appropriation too small to allow them to do their job as they should. The more sophisticated the operation, the more expensive it will be. However, because over the past five years Connecticut's annual rainfall has decreased a total of about 12 inches, and because the national spotlight has been focused on your water problem, you might fare better in this regard than we have.

\section{CONCLUSION}

This paper has rather vaguely covered a number of considerations and possibilities for Connecticut's future water program. Hopefully, some of it may be of value. If there is one idea that you should retain, it is that an inadequate plan is easy to make, but difficult to change. One can't urge strongly enough that you spend much time in research and investigations; that you formulate an overall policy; and that you then obtain laws which will realistically effectuate this policy.

\footnotetext{
*B.S., LL.B., LL.M., Attorney, Natural Resource Economics Division, Economic Research Service, United States Department of Agriculture; Assistant Director of Research, Legal Institute of Agricultural and Resource Development; and Assistant Professor of Law, University of Mississippi. The opinions expressed in this paper are those of the author, and do not necessarily reflect the opinions of the United States Department of Agriculture.
} 